\title{
Buenas prácticas en proyectos de divulgación de datos abiertos en el ámbito cultural: el caso de México
}

\author{
Verónica Susana Lerma Hernández | maestrante de la Universidad Nacional Autónoma de México \\ María Luisa Hernández Cruz | maestrante de la Universidad Iberoamericana
}

URL de la contribución <www.iaph.es/revistaph/index.php/revistaph/article/view/3967>

\section{Introducción}

En los últimos años las instituciones culturales en México han implementado una serie de proyectos digitales enfocados a la publicación de datos sobre el patrimonio cultural específicamente en las áreas de patrimonio artístico, histórico, arqueológico y paleontológico. Si bien, este tipo de estrategias se desarrollan debido a que la normatividad vigente promueve poner a disposición de la ciudadanía datos generados por las dependencias y entidades de la Administración Pública Federal (DOF: 20/02/2015), en nuestra experiencia los avances que se han alcanzado son limitados debido a una serie de factores tanto administrativos, logísticos y de planeación que han derivado en la publicación de sitios e información que no cumplen con las características de acceso, reutilización e interoperabilidad que se pretende impulsar.

Queremos centrar la atención, en particular, en lo que se conocen como buenas prácticas, debido a que, consideramos, son base fundamental para el éxito de una estrategia de publicación de datos culturales y porque nos hemos percatado de que pocas veces son tomadas en cuenta y son causa de limitaciones en los portales de datos en materia de cultura.

\section{Buenas prácticas en materia de datos abiertos}

Por buenas prácticas se entiende las acciones que han sido efectivas en contextos similares que logran mejores soluciones, métodos y procedimientos y por tanto se instituyen como prácticas recomendadas. Existen distintas guías escritas por instituciones y expertos en todo el mundo que contienen elementos en común y que se pueden clasificar en: a) Normatividad y aspectos legales; b) Plataformas, infraestructura de publicación y comunicación; contenidos y formatos; c) Documentación de procesos para la generación y mantenimiento de datos y metadatos.

a) Normatividad y aspectos legales. Este apartado se refiere a los requisitos legales, licencias para el uso y distribución de la información, tipo de datos y metadatos con sus niveles de acceso y confidencialidad.

Este es un tema que se discute mucho en las instituciones culturales en México ya que el universo de información que generan es por demás variado. Lo mismo se cuenta con catálogos fotográficos o bancos de imágenes que en algún tiempo para su acceso tuvieron un costo monetario, versando así la discusión en dar acceso res-

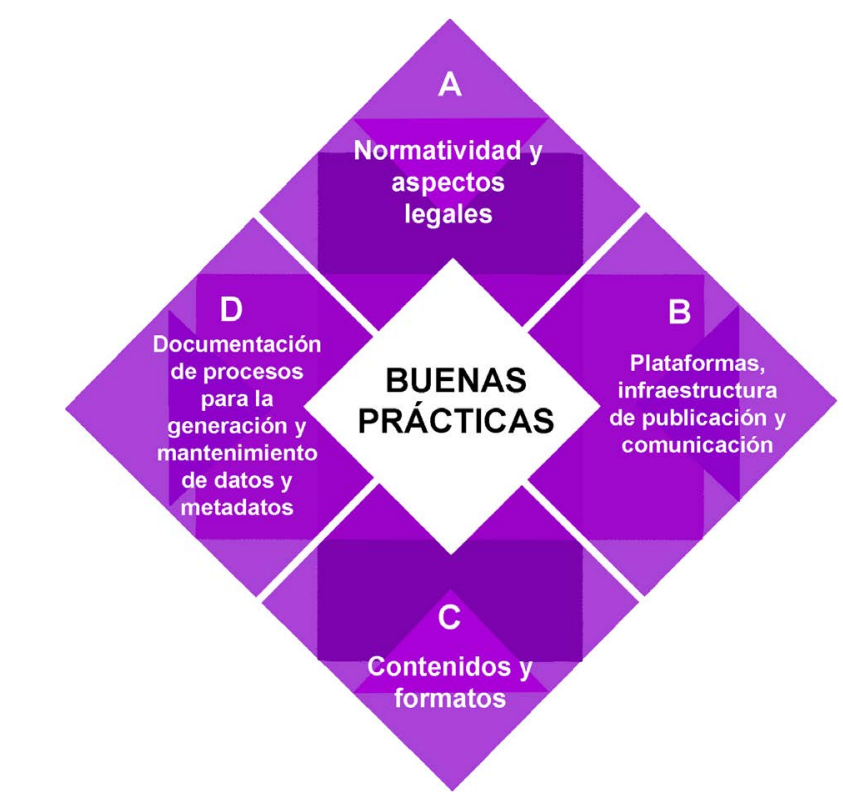

Clasificación de buenas prácticas | gráfico elaboración de los autores 
a debate Datos abiertos en instituciones culturales

| coordina Isabel Medrano Corrales

tringido con imágenes a baja resolución o permitir su descarga. Pero, además, se trata de información sobre sitios patrimoniales y en muchos de los casos su divulgación puede atentar contra su estado de conservación, como es el caso de sitios arqueológicos o paleontológicos, por lo que el acceso a su faceta espacial es limitada.

b) Plataformas, infraestructura de publicación y comunicación. En relación con este tópico el desarrollo en plataformas no comprometidas con algún software comercial, la interoperabilidad de las plataformas o la forma de distribución de datos son características indispensables en el diseño de las infraestructuras informáticas para dar acceso a los datos.

Para el caso de México y el conocimiento y experiencia en el manejo de herramientas digitales dentro del sector cultural es muy reciente. Esto ha dificultado la implementación de proyectos que cumplan con las características tecnológicas recomendadas, y que se apeguen a estándares de catalogación, publicación y de calidad, toda vez que son proyectos que deben ser implementados en corto tiempo, es decir, los proyectos se implementan pero no se garantizan ni su preservación, ni su difusión a largo plazo.

c) Contenidos y formatos. La variedad de acervos que resguardan las instituciones culturales (colecciones hemerográficas, bibliográficas, bancos de imágenes, fotografías, videos y fonogramas, catálogo de datos sobre sitios arqueológicos, históricos, entre otros) obliga a abrir la discusión en torno a una definición de metadata que sea adecuada, compatible, y estandarizada de acuerdo a la diversidad de los recursos y a utilizar los formatos digitales apropiados para cada tipo.

d) Documentación de procesos para la generación y mantenimiento de datos y metadatos. Por último, uno de los aspectos a considerar es la elaboración de documentos que fijen los procedimientos para la integración y conservación de datos y metadatos, así como las características de la información, los formatos para la preservación, entre otros, con el fin de garantizar la sus- tentabilidad y continuidad de los proyectos aún con el cambio de administraciones y de personal.

Uno de los grandes retos, que tienen que enfrentar las instituciones del sector cultural, es asegurar que la estrategia de difusión sea permanente, porque ésta suele depender del personal especializado a cargo. Un cambio de administración representa la pérdida del conocimiento y la experiencia en la ejecución del proyecto. Documentar los procesos apoyaría la continuidad y mejora de los mismos.

\section{Algunas ideas para la implementación de buenas prácticas}

Derivado de lo anterior y con el fin de contribuir a la implementación de buenas prácticas en los proyectos de datos abiertos sugerimos algunas acciones:

> Organizar grupos de trabajo para compartir experiencias, problemáticas, estrategias y soluciones.

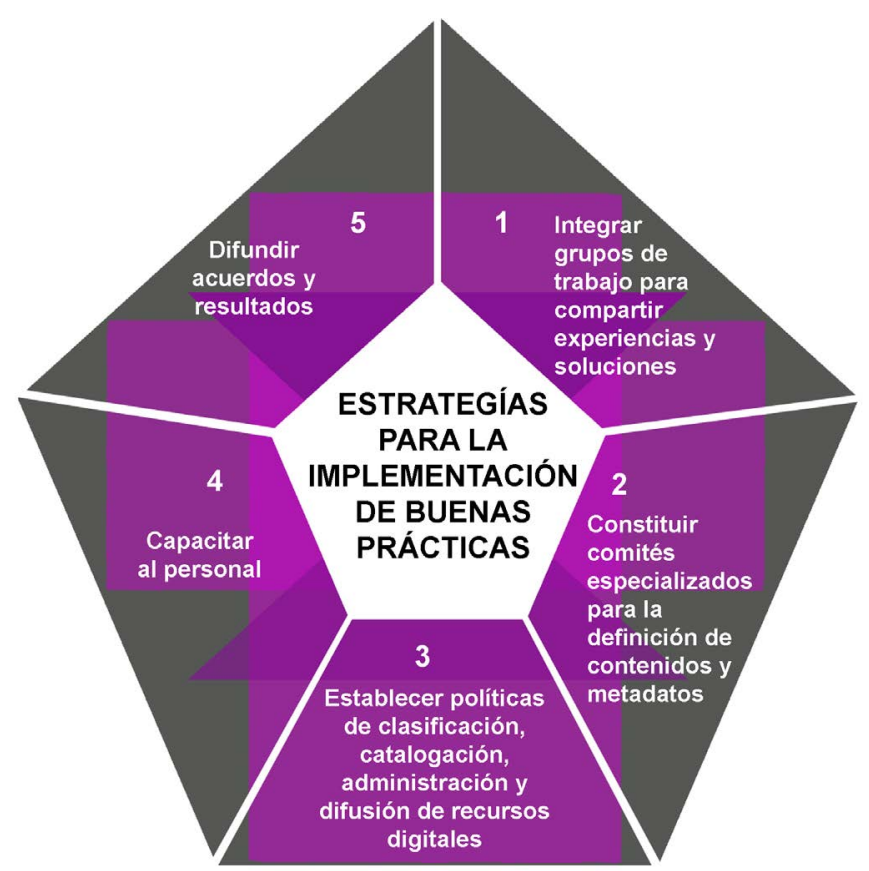

Estrategias para la implementacion de buenas prácticas | gráfico elaboración de los autores 